\title{
Recycled Water Reuse Permit Renewal Application for the Central Facilities Area Sewage Treatment Plant
}

Mike Lewis

September 2014

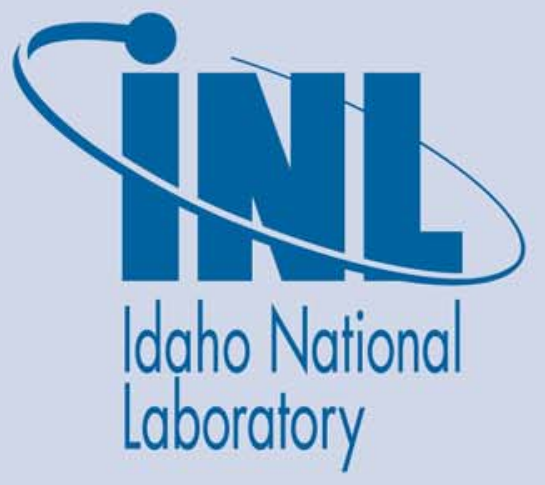

The INL is a U.S. Department of Energy National Laboratory operated by Battelle Energy Alliance 


\title{
Recycled Water Reuse Permit Renewal Application for the Central Facilities Area Sewage Treatment Plant
}

Mike Lewis

September 2014

\author{
Idaho National Laboratory \\ Idaho Falls, Idaho 83415
}

http://www.inl.gov

Prepared for the

U.S. Department of Energy

Office of Nuclear Energy

Under DOE Idaho Operations Office

Contract DE-AC07-05ID14517 


\begin{abstract}
This renewal application for a Recycled Water Reuse Permit is being submitted in accordance with the Idaho Administrative Procedures Act 58.01.17 "Recycled Water Rules" and the Municipal Wastewater Reuse Permit LA000141-03 for continuing the operation of the Central Facilities Area Sewage Treatment Plant located at Idaho National Laboratory. The permit expires March 16,2015 . The permit requires a renewal application to be submitted 6 months prior to the expiration date of the existing permit. For the Central Facilities Area Sewage Treatment Plant, the renewal application must be submitted by September 16, 2014. The information in this application is consistent with the Idaho Department of Environmental Quality's Guidance for Reclamation and Reuse of Municipal and Industrial Wastewater and discussions with Idaho Department of Environmental Quality personnel.
\end{abstract}




\section{CONTENTS}

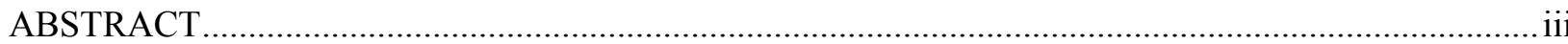

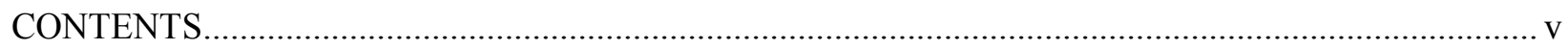

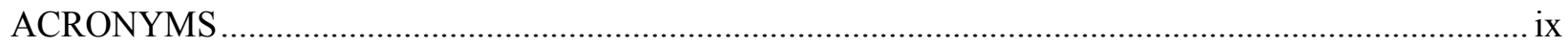

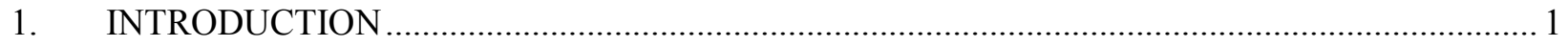

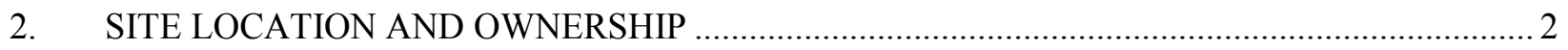

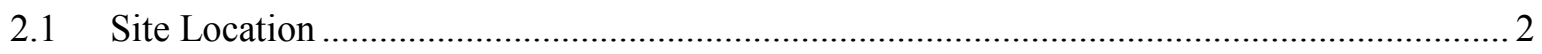

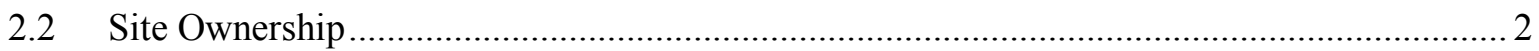

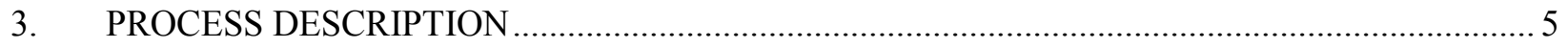

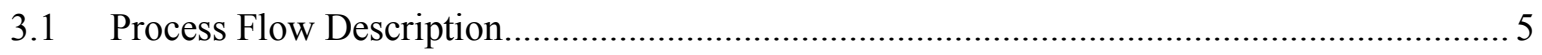

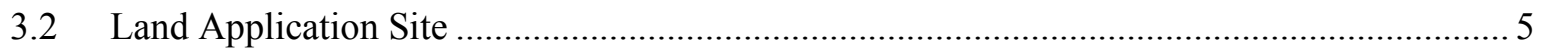

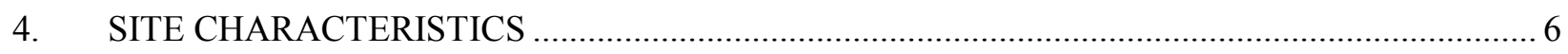

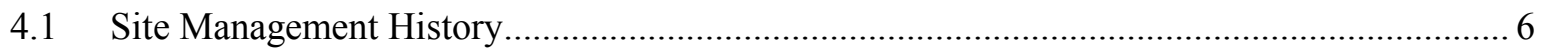

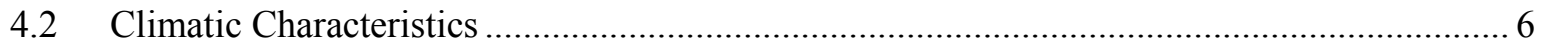

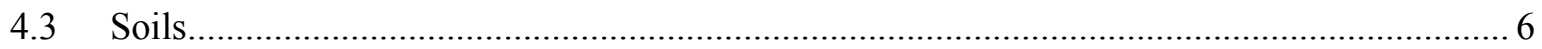

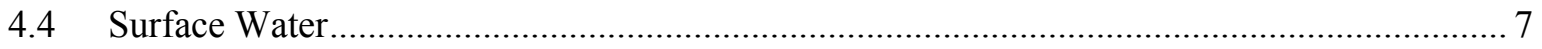

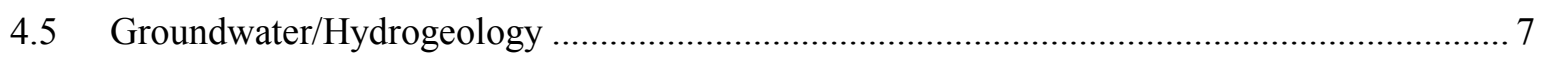

5. WASTEWATER CHARACTERIZATION, CROPPING PLAN, AND LOADING RATES .......... 9

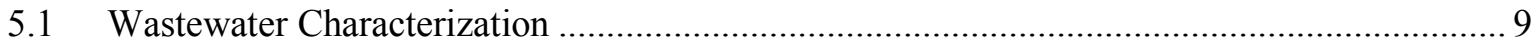

5.1.1 Volume of Wastewater Applied to the Land Application Site................................... 9

5.1.2 Concentrations of Key Constituents in the Wastewater............................................ 10

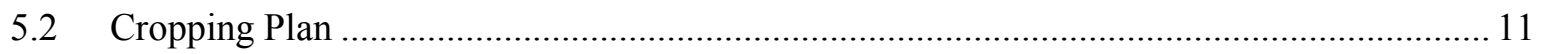

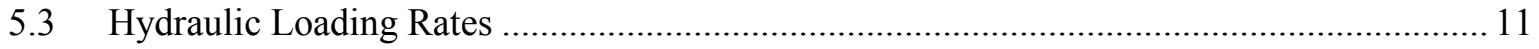

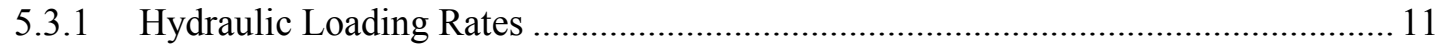

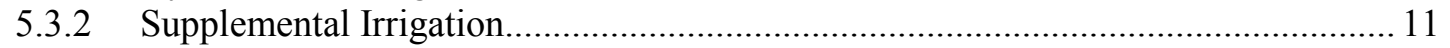

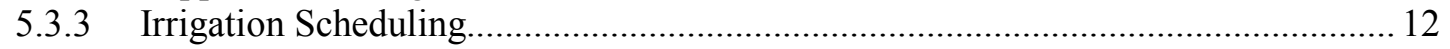

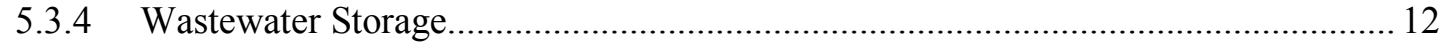

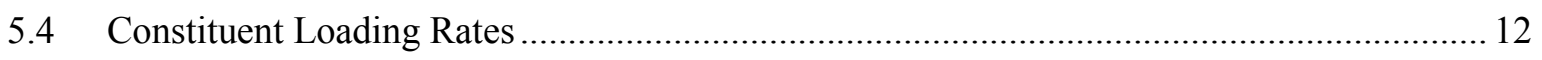

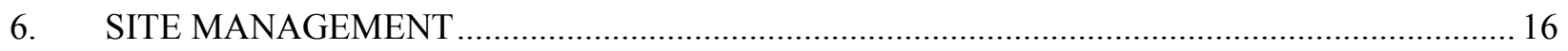

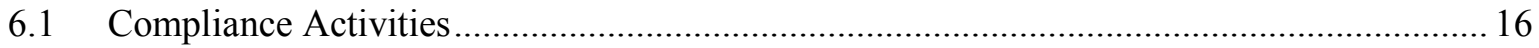

6.1.1 CA-141-01 - Plan of Operation ..................................................................... 16

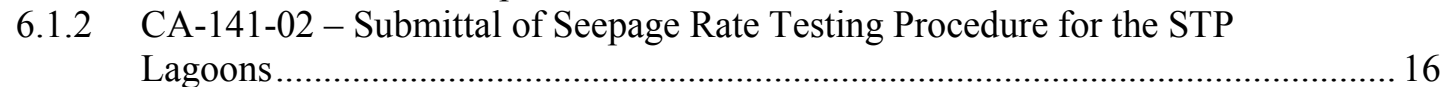

6.1.3 CA-141-03 - Complete Seepage Testing of the Three CFA STP Lagoons ............... 16

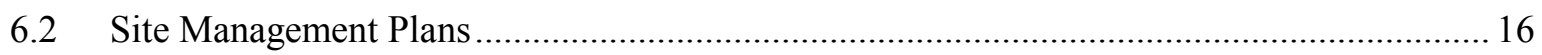

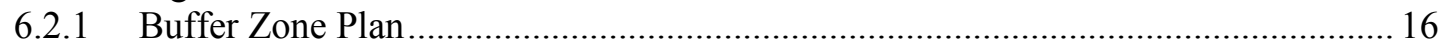

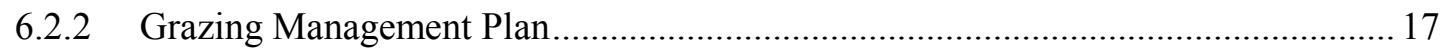

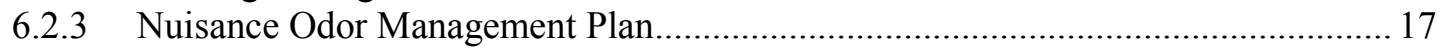




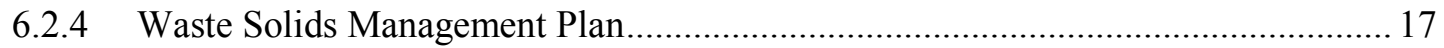

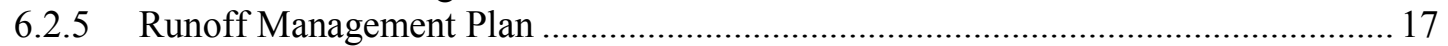

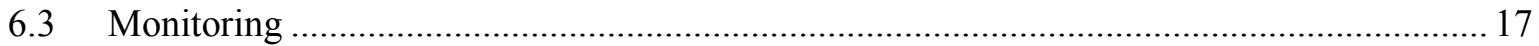

6.3.1 Monitoring the Quantity of Land Applied Wastewater ............................................. 17

6.3.2 Sampling and Analysis of Land-Applied Wastewater .............................................. 18

6.3.3 Method of Calculating Hydraulic and Constituent Loading ...................................... 18

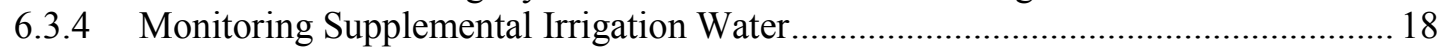

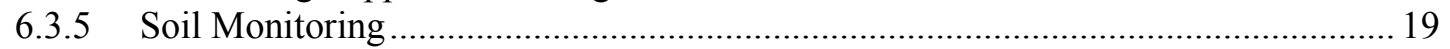

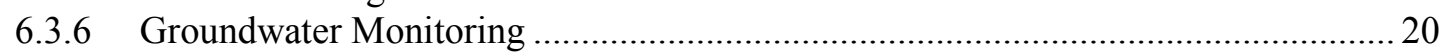

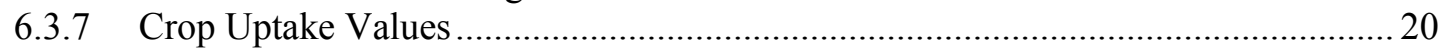

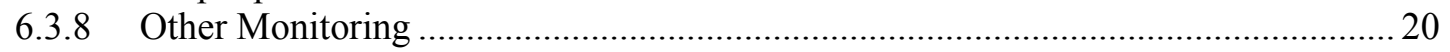

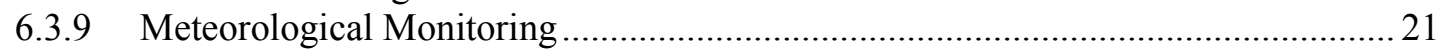

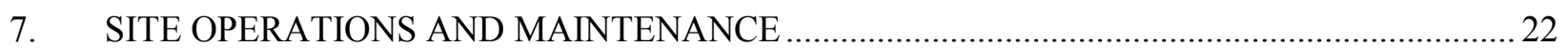

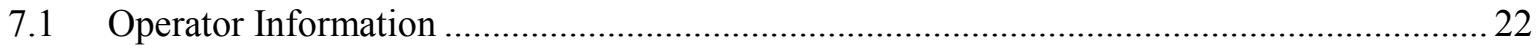

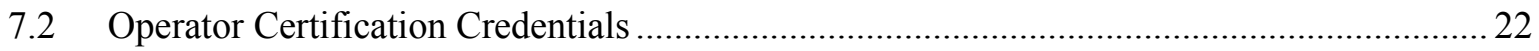

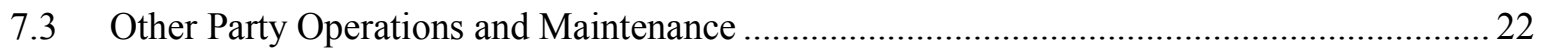

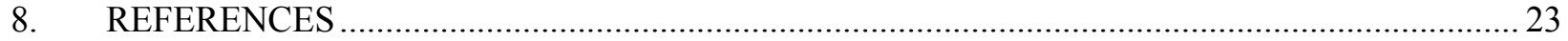

\section{FIGURES}

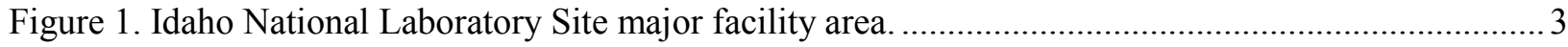

Figure 2. Central Facilities Area Sewage Treatment Plant monitoring locations, lagoons, and land

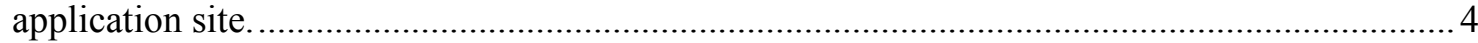

Figure 3. Locations of monitoring and potable/production wells near the Central Facilities Area

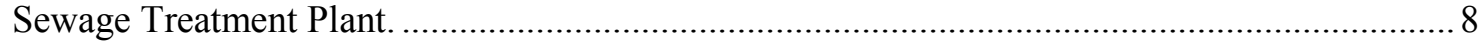

Figure 4. Annual effluent flow to the Central Facilities Area Sewage Treatment Plant land

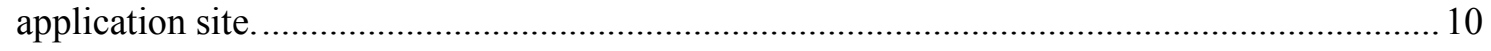

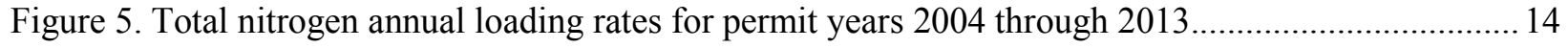

Figure 6. Total phosphorous annual loading rates for permit years 2004 through 2013 ........................ 15

\section{TABLES}

Table 1. Wastewater applied to the Central Facilities Area Sewage Treatment Plant land application site for Reporting Years 2004 through 2013 ...................................................... 9

Table 2. Central Facilities Area Sewage Treatment Plant 2004 through 2013 effluent permit year

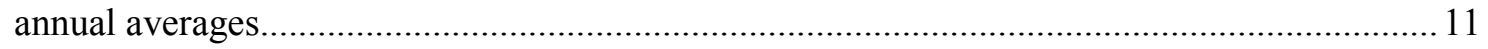

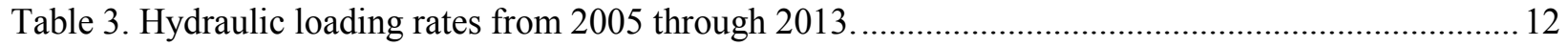

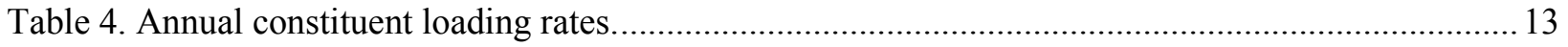

Table 5. Buffer zone distances from the Central Facilities Area land application area........................... 17 
Table 6. Central Facilities Area Sewage Treatment Plant application area soil monitoring results for the period of 2005 through $2013 .$.

Table 7. Central Facilities Area Sewage Treatment Plant wastewater system operators....... 


\section{ACRONYMS}

BEA Battelle Energy Alliance, LLC

bls below land surface

CES Cascade Earth Sciences

CFA Central Facilities Area

COD chemical oxygen demand

CERCLA Comprehensive Environmental Response, Compensation, and Liability Act

DEQ Idaho Department of Environmental Quality

DOE-ID U. S. Department of Energy Idaho Operations Office

gpd gallons per day

IDAPA Idaho Administrative Procedures Act

INL Idaho National Laboratory

MG million gallons

MOS meteorological observation station

MS Monitoring Services

NNN nitrate + nitrite nitrogen

NOAA National Oceanic and Atmospheric Administration

NS not sampled

STP Sewage Treatment Plant

TDS total dissolved solids

TKN total Kjeldahl nitrogen

$\mathrm{TN} \quad$ total nitrogen

USGS United Stated Geological Survey 


\section{Recycled Water Reuse Permit Renewal Application for the Central Facilities Area Sewage Treatment Plant \\ 1. INTRODUCTION}

This renewal application for a Recycled Water Reuse Permit has been prepared in compliance with Idaho Administrative Procedures Act (IDAPA) 58.01.17, "Recycled Water Rules," for the continued operation of the Central Facilities Area Sewage Treatment Plant (CFA STP) and discussions with Idaho Department of Environmental Quality personnel during the pre-application meeting. The CFA STP is currently permitted by the Idaho Department of Environmental Quality (DEQ) under Municipal Wastewater Reuse Permit LA-000141-03 issued by the DEQ. The current permit was issued on March 17, 2010, (Neher 2010) and will expire on March 16, 2015.

The information in this permit renewal application is presented in the order listed in the "Suggested Outline for Preparing the Technical Report" found in Section 1.5 of the DEQ Guidance for Reclamation and Reuse of Municipal and Industrial Wastewater (DEQ 2007). 


\section{SITE LOCATION AND OWNERSHIP \\ 2.1 Site Location}

The INL Site encompasses approximately 890 square miles of land used for energy and national security research operations (Figure 1). Only about $2 \%$ of the land within the INL Site has been developed for industrial-type research operations, parking areas, roads, etc. The CFA STP is located on the INL Site in Butte County, Idaho approximately 42 miles west of Idaho Falls. The legal location of the CFA STP is T2N, R29E, Section 1 and T2N, R30E, Section 6 (United States Geological Survey (USGS), North of Scoville Quadrangle).

The CFA STP is located southeast of the CFA, approximately 2.5 miles northwest of the U.S. Highway 20/26 junction. The nearest cities are Atomic City (Figure 1), approximately 8 miles southeast of CFA and the city of Arco, approximately 20 miles west of CFA. The CFA STP is approximately 2,200 $\mathrm{ft}$ down gradient of the nearest drinking water well and 4,400 ft north of Highway 26. The wastewater land application site is approximately 1,400 ft from the nearest inhabited building (Figure 2).

The remaining areas are comprised of relatively undisturbed high desert land. Public access is restricted to the highways that cross the INL Site and there are no dwellings, canals/ditches, or private water sources on the INL Site.

\subsection{Site Ownership}

The INL Site is a government-owned, contractor-operated, facility managed by the Department of Energy's Idaho Operations Office (DOE-ID). Battelle Energy Alliance, LLC (BEA) is the current INL management and operating contractor responsible for operating the CFA STP and land application site. 


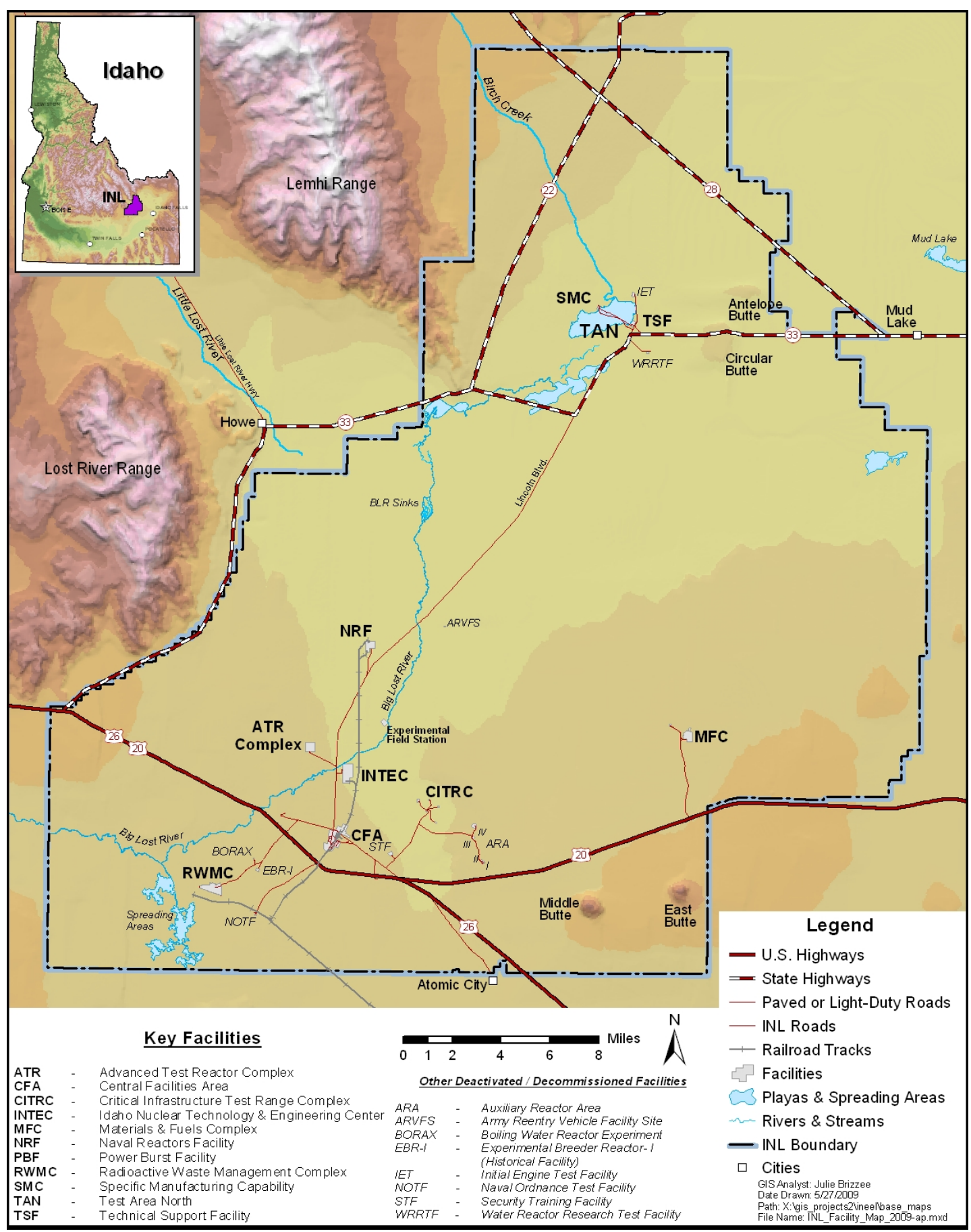

Figure 1. Idaho National Laboratory Site major facility area. 


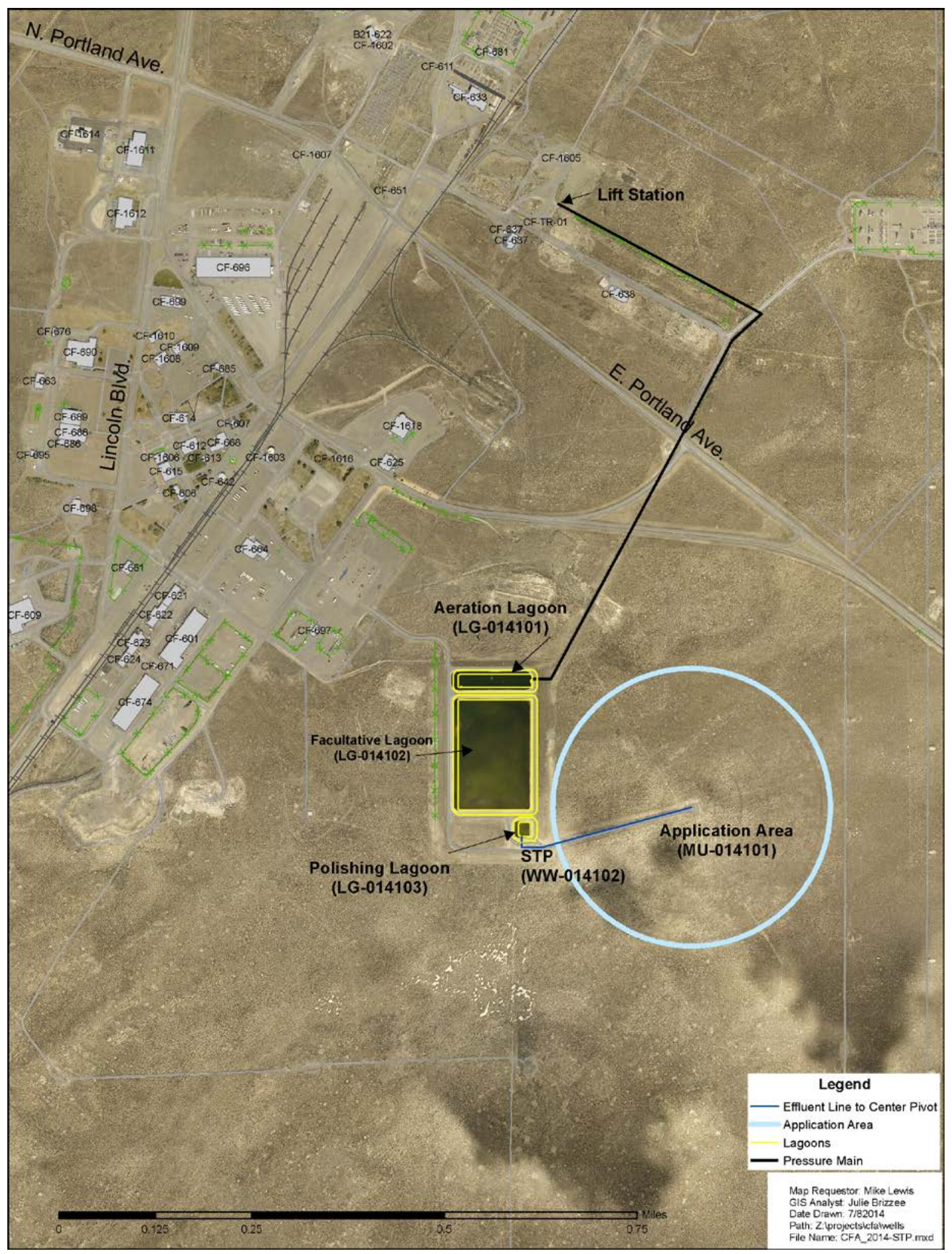

Figure 2. Central Facilities Area Sewage Treatment Plant monitoring locations, lagoons, and land application site. 


\section{PROCESS DESCRIPTION}

\subsection{Process Flow Description}

The CFA STP processes wastewater derived from sanitary and industrial sewer drains throughout CFA. The wastewater comes from restrooms, showers and kitchen facilities. Other contributing discharge sources include those associated with bus and vehicle maintenance areas, analytical laboratory operations, boiler blowdown, a firestation and a medical dispensary. The CFA STP also receives and treats wastewater from INL septic tanks, portable toilets, comfort stations, and other nonroutine sources.

Major components of the CFA STP include a wastewater lift station, pressure main, lagoon system, and a pivot irrigation land application system (Figure 2). The lagoon system consists of a 1.7-acre treatment lagoon (Lagoon 1) with partial-mix aeration capabilities, a 10.3-acre facultative lagoon (Lagoon 2), and a 0.5 -acre polishing pond (Lagoon 3). Land application of treated wastewater is by a $350 \mathrm{gpm}$ pivot irrigation system.

Sanitary and industrial wastewater is pumped from the main lift station (CF-1718) into a 1.7-acre lagoon for initial treatment. The treatment lagoon uses mechanical aeration to mix and oxygenate the wastewater and facilitate treatment. Enhancing the initial treatment lagoon with aerators serves to keep portions of the surface of the lagoon free from ice during the winter, reduces odor, and maximizes turnover in the spring and fall. Water depth remains relatively constant to ensure adequate treatment by aerobic bacteria. Wastewater from the initial treatment lagoon flows by gravity to a 10.3-acre facultative lagoon. From the facultative lagoon, wastewater flows to the 0.5 -acre polishing pond for settling of any remaining suspended solids before discharge by a 15 -horsepower pump to the pivot irrigation system for land application.

The CFA STP wastewater main lift station (CF-1718) utilizes two submersible $20 \mathrm{hp}$, Chopper Pumps with a design flow rate of 350 gpm.

There have been no major changes to the wastewater system since the previous permit application.

\subsection{Land Application Site}

The CFA STP land application site is 73.5-acres. Vegetation on the land application site consists of both native and non-native desert rangeland plants. No crops are grown or harvested and no domestic animals are allowed to graze on the vegetation. The land application site is designated by the current permit as hydraulic management unit MU-01-014101.

The pivot irrigation system equipment includes a circle pivot, suspended pipeline, nozzles, end gun, wind speed monitor, flow meter, valving, and motors to drive the wheels. Controls are located at the pivot. 


\section{SITE CHARACTERISTICS}

\subsection{Site Management History}

The INL Site is a federal reserve currently under the jurisdiction of DOE-ID. It is approximately $890 \mathrm{mi}^{2}$, covering portions of five counties on the northeastern edge of the Snake River Plain. The CFA is located in the southwest portion of the INL Site. The CFA STP land application site lies southeast of CFA.

Wastewater was first applied to the land application site in May 1995 (INEL 1995). No crops are grown, no domestic livestock are grazed, and no fertilizer has been applied to the CFA STP land application site.

\subsection{Climatic Characteristics}

The climate at the INL Site is affected by its altitude above sea level, its latitude, and its intermountain setting. Annual rainfall at the INL Site is light, and the region is classified as arid to semiarid. The relatively dry air and infrequent low clouds permit intense solar heating of the surface during the day and rapid radiational cooling at night. These factors combine to give a large diurnal range of temperature near the ground surface (Clawson, Start, and Ricks 1989).

National Oceanic and Atmospheric Administration (NOAA) operate several meteorological observation stations (MOS) at the INL Site. The oldest MOS at the INL Site is located at CFA and was established in 1949 (Clawson, Start, and Ricks 1989). Data from this MOS for the period of calendar years 2004 through 2013 (Rich 2014) are presented below:

- Average annual precipitation for the 10 -year period was 6.78 inches

- Minimum monthly precipitation was 0.00 inches and occurred during the months of March 2004, July 2005, and August 2013

- Maximum monthly precipitation was 3.56 inches and occurred during May 2005

- Average summer (June through August) temperature was $65.8^{\circ} \mathrm{F}$

- Average winter (December through February) temperature was $20.5^{\circ} \mathrm{F}$

- Extreme daily low temperature of $-30^{\circ} \mathrm{F}$ occurred on December 7, 2005 and January 22, 2008

- Extreme daily high temperature of $102^{\circ} \mathrm{F}$ occurred on July 23, 2007 and July 30, 2007

- Winds at the INL Site are generally from the southwest.

\subsection{Soils}

In 1993, the services of Cascade Earth Sciences (CES) were retained to determine whether the soils located in the current land application site were suitable for wastewater application (CES 1993). Seven test pits were completed on the land application site. Soils were classified according to the United States Department of Agriculture System (USDA 1981).

Soils at the land application site were determined to be formed from loess and eolian sands, which in places overlie sediments and fractured basalt. These occur on a nearly level, 0 to $1 \%$ slope. The predominant texture to 6 inches is silty clay loam. Below this depth, soils are predominantly silt loam to 52 inches. Soils exhibit well-drained properties throughout the application site. The average soil depth to bedrock exceeded 40 inches in the seven test pits. 
Soil data from the land application site for the period of 2005 through 2013 is summarized in Section 6.3.5 of this application.

\subsection{Surface Water}

The nearest surface water to the land application site is the Big Lost River. It is located approximately 3.0 miles northwest of the land application site. Big Lost River waters are impounded and regulated by the Mackay Dam located approximately 4 miles northwest of Mackay, Idaho. A number of irrigation diversions exist between the Mackay Dam and the INL Site. Due to water storage in the Mackay Reservoir, irrigation, infiltration, and evaporation, the Big Lost River only flows infrequently onto the INL Site.

The 100-year Big Lost River floodplain was determined by the U. S. Department of Energy in conjunction with the U.S. Bureau of Reclamation. Activities and facilities on the INL Site are considered to be within the 100-year Big Lost River floodplain if they are within the areas shown on sitewide maps found in the Big Lost River Flood Hazard Study (Ostenaa and O'Connell 2005). These maps and analyses indicate that the CFA STP is not within the Big Lost River 100-year floodplain. Based on this floodplain study, the hypothetical 100-year Big Lost River floodplain is about 3.0 miles from the location of the CFA STP.

There are no active canals, wetlands, or springs in the immediate vicinity of the CFA STP. The CFA STP does not influence nearby surface waters and does not have a surface water discharge point.

\subsection{Groundwater/Hydrogeology}

The Eastern Snake River Plain Aquifer lies under the INL Site. Groundwater in the Eastern Snake River Plain Aquifer at the CFA STP is approximately $500 \mathrm{ft}$ below ground surface. Regional and local groundwater flow is generally to the south-southwest. Figure 3 shows aquifer monitoring and production wells within the general vicinity of the CFA STP.

Well CFA-MON-A-003 is located within $1 / 4$ mile of the CFA STP land application site. Well USGS130 is located within $1 / 4$ mile of the CFA STP lagoons. Well CFA-MON-A-003 is monitored for Comprehensive Environmental Response, Compensation, and Liability Act (CERCLA) purposes. The completion depth of the well is 510.90 feet below land surface (bls). Depth to water from this well taken on August 14, 2013 was 491.97 feet bls.

Wells CFA-MON-A-001, CFA-MON-A-002, and CFA-1931 are also CERCLA monitoring wells.

Well USGS-130 is monitored by USGS for water level. The completion depth of the well is 639 feet bls. Depth to water for USGS-130 on September 9, 2013 was 485.52 bls.

Wells CFA-1 and CFA-2 are potable/production wells. These two wells are generally upgradient of the CFA STP.

A well location acceptability analyses has not been performed on the two wells located within a $1 / 4$-mile of the CFA STP because the wells are used for monitoring purposes only and are not used as a public drinking water supply. 


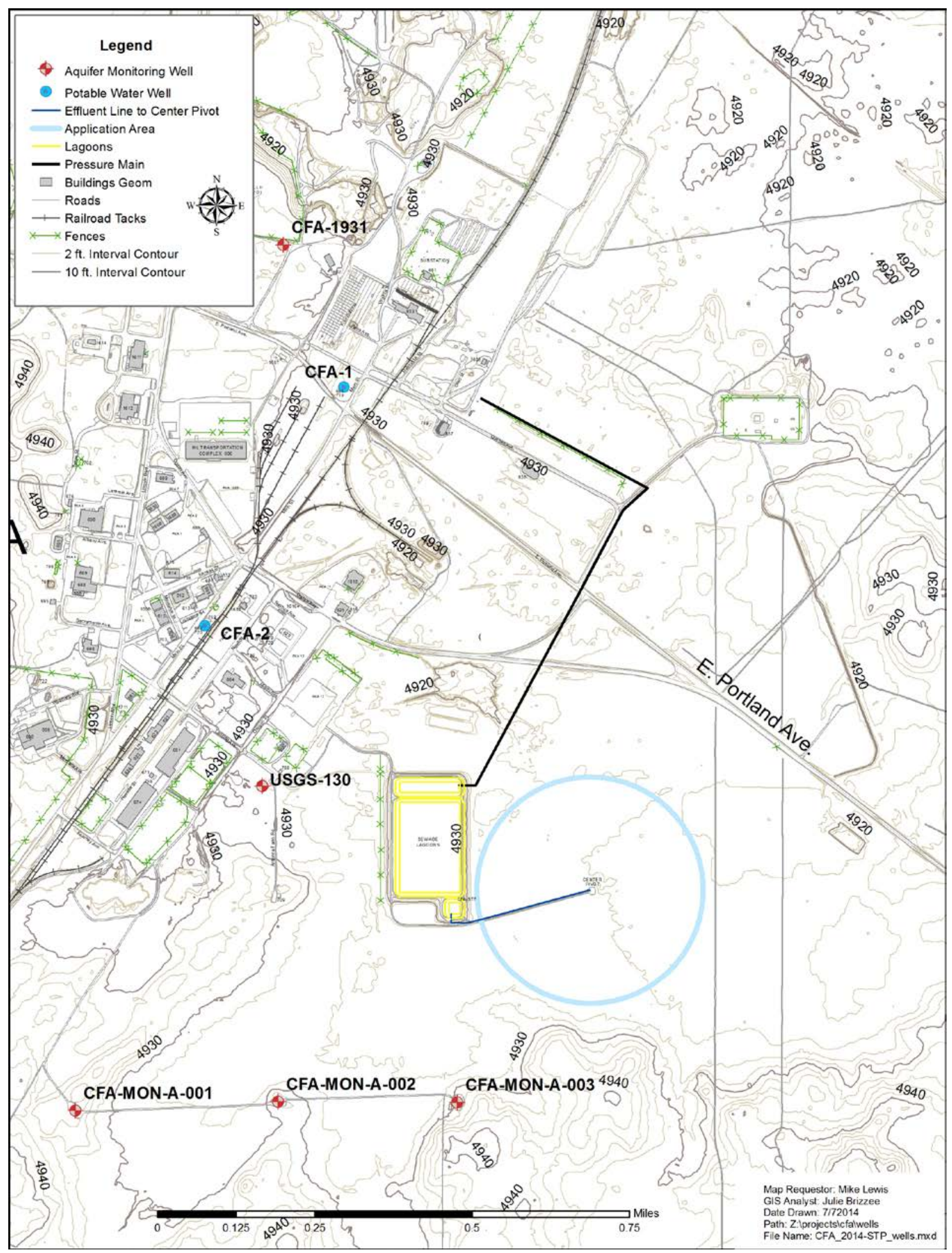

Figure 3. Locations of monitoring and potable/production wells near the Central Facilities Area Sewage Treatment Plant. 


\section{WASTEWATER CHARACTERIZATION, CROPPING PLAN, AND LOADING RATES}

\subsection{Wastewater Characterization}

\subsubsection{Volume of Wastewater Applied to the Land Application Site}

Table 1 shows the volumes of wastewater applied to the CFA STP land application site from permit year 2004 through 2013. These volumes are taken from the CFA STP annual site performance reports (ICP 2005, Mascareñas 2006b, Graham 2007, Stenzel 2008, Stenzel 2009, Stenzel 2010, Stenzel 2011 a, Stenzel 2012, Stenzel 2013, and Mascareñas 2014) and are derived from the daily flow meter readings at the pivot (WW-014102). The volume of wastewater discharged to the land application site has decreased significantly since 2004 (Figure 4). The volume of wastewater generated at CFA has continued to decline during recent years due to closures of facilities and associated processes. Buildings that have been demolished or inactivated during the past 5 years include:

- $\quad$ CF-614 - Office Building sinks and restrooms

- CF-629 - Office Building, sinks and restrooms

- CF-666 - Maintenance Support Building, sinks, restrooms, showers, and kitchen

- CF-685 - Bus Passenger Shelter, sinks, and restrooms (building continues to be used, but sinks and restrooms have been deactivated)

- CF-686 - High Bay, sink (building modified and sink removed)

- CF-690 - Radiological Environmental Lab, sinks, restrooms, floor drains, showers, kitchen, and laboratory sinks

- CF-1605 - CFA Waste Water Laboratory, restrooms, sinks, and showers.

No new buildings/processes are currently being planned for CFA.

Table 1. Wastewater applied to the Central Facilities Area Sewage Treatment Plant land application site for Reporting Years 2004 through 2013.

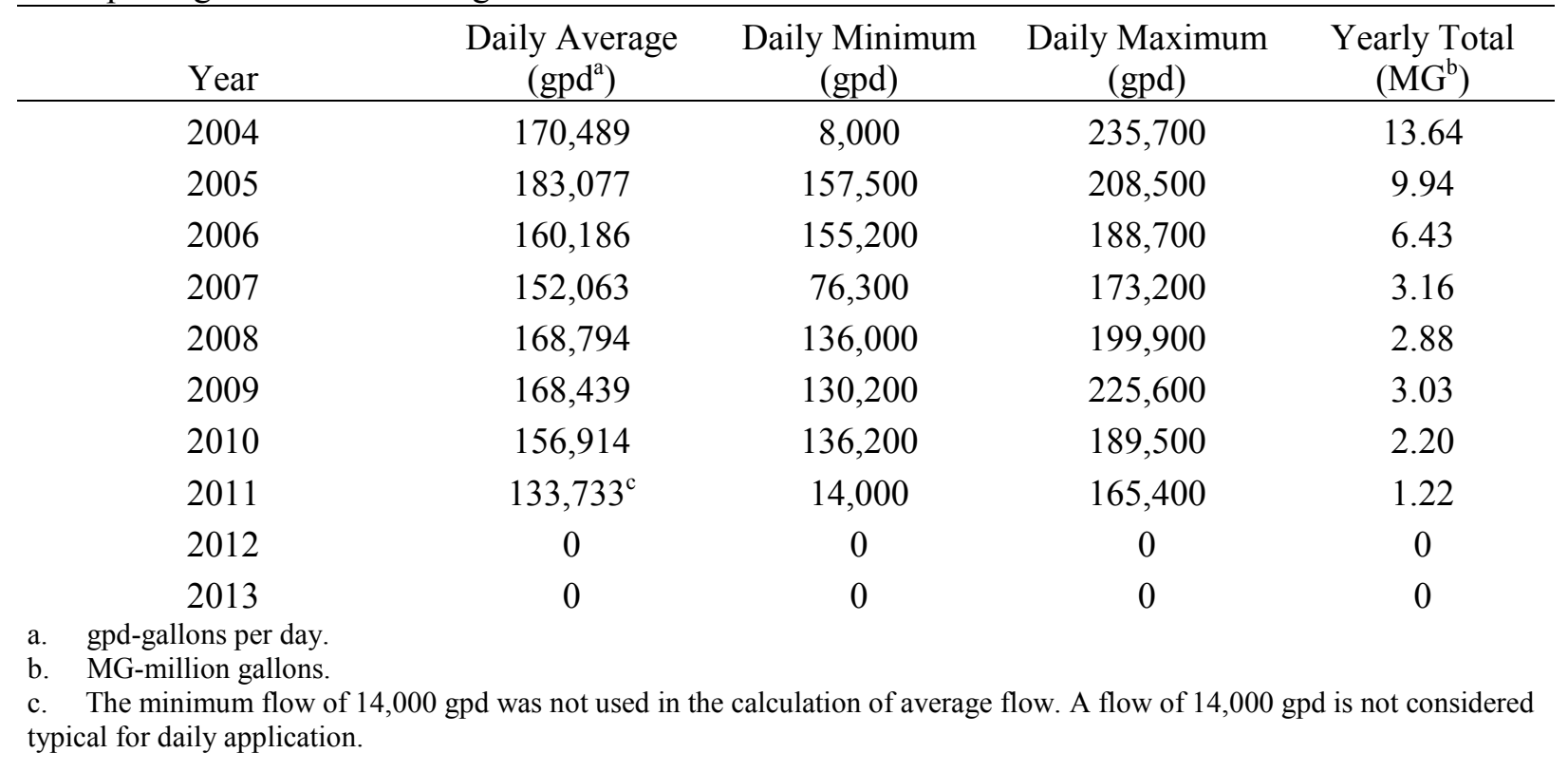




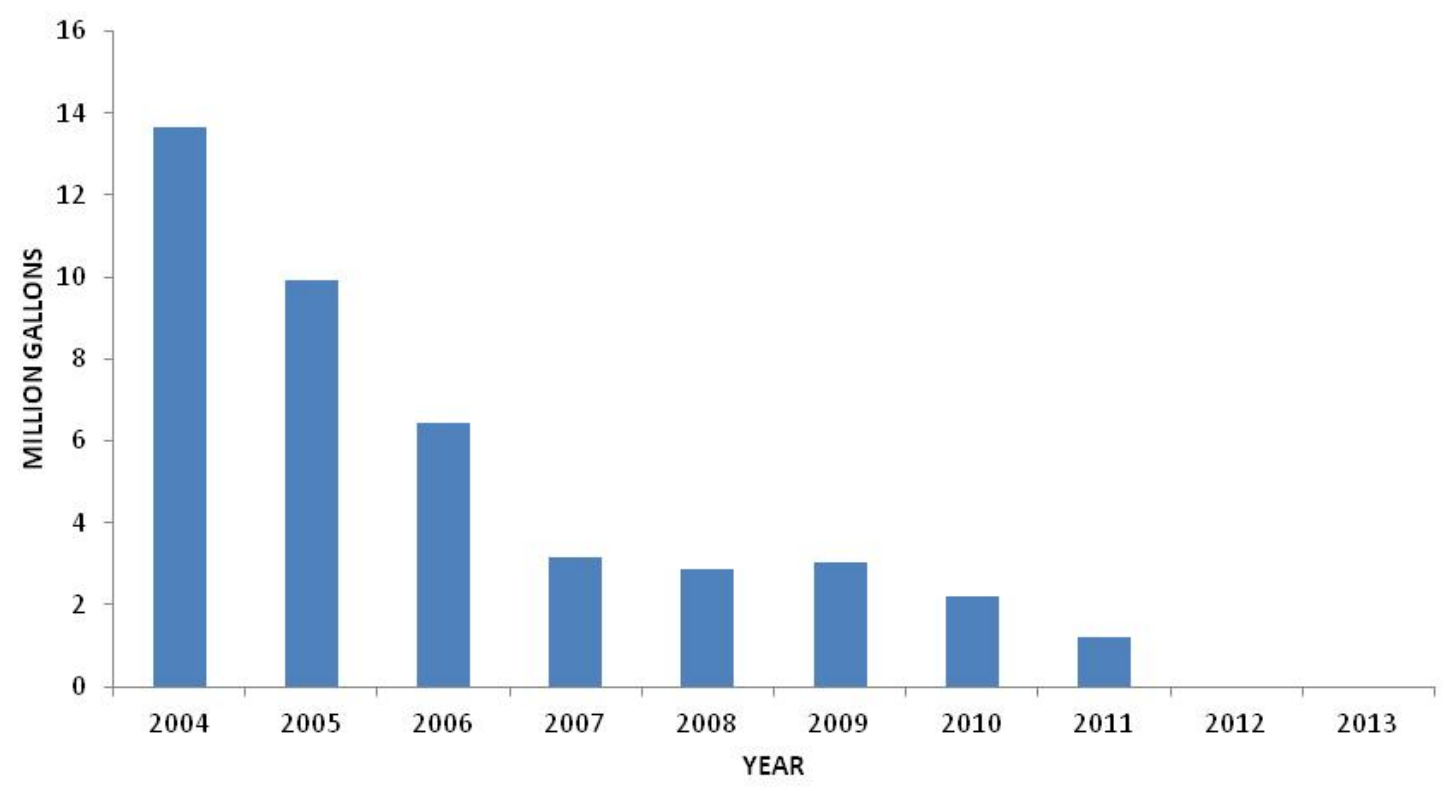

Figure 4. Annual effluent flow to the Central Facilities Area Sewage Treatment Plant land application site.

\subsubsection{Concentrations of Key Constituents in the Wastewater}

Table 2 summarizes the wastewater effluent data collected at effluent to the pivot (WW-014102) for permit years 2004 through 2013. The parameters listed in Table 2 are those required by permit LA000141-03 with an effective date of March 17, 2010. In 2009, 2010, and 2011, only a single monthly sample was collected due to the limited amount of wastewater land applied. No wastewater was land applied in 2012 and 2013; therefore, no permit effluent samples were collected. There are no specific constituent limits identified in the permit for the effluent. 
Table 2. Central Facilities Area Sewage Treatment Plant 2004 through 2013 effluent permit year annual averages.

\begin{tabular}{|c|c|c|c|c|c|c|c|c|}
\hline $\begin{array}{c}\text { Annual } \\
\text { Averages }^{\mathrm{a}}\end{array}$ & $\begin{array}{c}\mathrm{TKN}^{\mathrm{b}} \\
(\mathrm{mg} / \mathrm{L})\end{array}$ & $\begin{array}{l}\mathrm{NNN}^{\mathrm{c}} \\
(\mathrm{mg} / \mathrm{L})\end{array}$ & $\begin{array}{c}\mathrm{TN}^{\mathrm{d}} \\
(\mathrm{mg} / \mathrm{L})\end{array}$ & $\begin{array}{l}\mathrm{COD}^{\mathrm{e}} \\
(\mathrm{mg} / \mathrm{L})\end{array}$ & $\begin{array}{c}\mathrm{TDS}^{\mathrm{f}} \\
(\mathrm{mg} / \mathrm{L})\end{array}$ & $\mathrm{pH}$ & $\begin{array}{c}\text { Total } \\
\text { Phosphorus } \\
\text { (mg/L) }\end{array}$ & $\begin{array}{c}\text { Total } \\
\text { Coliform } \\
(100 \mathrm{~mL})\end{array}$ \\
\hline 2004 & 0.63 & 0.006 & 0.64 & 27.10 & $\mathrm{NS}^{\mathrm{g}}$ & 9.74 & 0.17 & 7 \\
\hline 2005 & 2.03 & 0.025 & 2.06 & 39.24 & 992 & 8.78 & 0.60 & 23 \\
\hline 2006 & 2.48 & 0.076 & 2.56 & 45.60 & 1,071 & 8.81 & 1.32 & 7 \\
\hline 2007 & 2.19 & 0.239 & 2.43 & 38.70 & 1,203 & 9.16 & 0.188 & 3 \\
\hline 2008 & 2.78 & 0.212 & 2.99 & 53.45 & 1,040 & 9.38 & 0.528 & 3 \\
\hline 2009 & 2.25 & 0.183 & 2.43 & 46.60 & 1,160 & 9.33 & 0.293 & 1 \\
\hline 2010 & 4.58 & 0.151 & 4.73 & 47.60 & 1,200 & 9.11 & 0.888 & 3 \\
\hline 2011 & 1.99 & $0.25 \mathrm{U}$ & 2.12 & 59.8 & 1,460 & 9.59 & 0.374 & 16 \\
\hline 2012 & NS & NS & NS & NS & NS & NS & NS & NS \\
\hline 2013 & NS & NS & NS & NS & NS & NS & NS & NS \\
\hline \multicolumn{9}{|c|}{$\begin{array}{l}\text { a. Only a single monthly sample was collected for permit years } 2009,2010 \text {, and } 2011 . \\
\text { b. TKN - total Kjeldahl nitrogen. } \\
\text { c. NNN - nitrate+nitrite nitrogen. } \\
\text { d. TN - total nitrogen is the sum of TKN and nitrate+nitrite as nitrogen. For results reported below the instrument detection limit, half } \\
\text { the detection limit for that parameter is used in the calculation. } \\
\text { e. COD - chemical oxygen demand. } \\
\text { f. TDS - total dissolved solids. } \\
\text { g. NS - not sampled. For 2004, TDS was not a permit required parameter. For } 2012 \text { and 2013, no effluent was land applied; therefore, } \\
\text { no samples were required. }\end{array}$} \\
\hline
\end{tabular}

\subsection{Cropping Plan}

Desert steppe and crested wheatgrass vegetative communities occur on the land application site. No crops, trees, or vegetation are harvested on the CFA STP land application site. In addition, no domestic livestock are grazed on this site; therefore, a cropping plan is not required.

\subsection{Hydraulic Loading Rates}

\subsubsection{Hydraulic Loading Rates}

Table 3 provides monthly hydraulic loading rates to the land application site for 2005 through 2013 . Loading rates are presented in million gallons/acre and inches/acre. The permit specifies a maximum hydraulic loading rate of 37 million gallons annually on up to 73.5 acres and shall not exceed 18.5 acre-inches/acre/year. The annual loading rate has ranged from a high of 13.64 million gallons in 2004 to a low of zero gallons in 2012 and 2013 (Table 1). Hydraulic loading has been well below the permit limits.

\subsubsection{Supplemental Irrigation}

The permit does not allow supplemental irrigation. 
Table 3. Hydraulic loading rates from 2005 through 2013. ${ }^{a}$

\begin{tabular}{lcc}
\hline & \multicolumn{2}{c}{ Applied Wastewater } \\
\cline { 2 - 3 } \multicolumn{1}{c}{ Sample Month } & $\left(\mathrm{MG}^{\mathrm{b}} /\right.$ acre $)$ & (in./acre) \\
\hline June 2005 & 0.048 & 1.76 \\
July 2005 & 0.040 & 1.48 \\
August 2005 & 0.034 & 1.25 \\
September 2005 & 0.013 & 0.49 \\
June 2006 & 0.013 & 0.48 \\
July 2006 & 0.035 & 1.28 \\
August 2006 & 0.029 & 1.06 \\
September 2006 & 0.011 & 0.40 \\
June 2007 & 0.010 & 0.39 \\
August 2007 & 0.033 & 1.20 \\
June 2008 & 0.030 & 1.11 \\
July 2008 & 0.009 & 0.34 \\
September 2009 & 0.041 & 1.52 \\
August 2010 & 0.030 & 1.10 \\
August 2011 & 0.016 & 0.61 \\
2012 & 0 & 0 \\
2013 & 0 & 0 \\
& & \\
a. Loading rates calculated for wastewater application on 73.5 acres (hydraulic management unit MU-014101). \\
b. MG-Million gallons.
\end{tabular}

\subsubsection{Irrigation Scheduling}

The application season, as allowed by the permit, is April 1 through October 31 each year, weather permitting. Application is not allowed to be applied to frozen or snow covered ground. Typically, maintenance is performed on the pivot system in May and land application is started in June (Table 3) and is completed in September of each year. However, the permittee would like to maintain the flexibility of having the application period remain as April 1 through October 31.

\subsubsection{Wastewater Storage}

The CFA STP lagoons and application area were designed for irrigation during the growing season and effluent accumulation/storage during the remainder of the year. The design allowed for a total storage of approximately 30.5 million gallons of wastewater at a depth of $8 \mathrm{ft}$. Lagoons 2 and 3 have a combined capacity of approximately 26.7 million gallons. The water depth in those lagoons is typically reduced to approximately 4 -ft (13.1 million gallons) during the irrigation season which provides about 13.6 million gallons of storage capacity for the non-growing season. In 2012 and 2013, no wastewater had to be land applied. In 2013, approximately 7.68 million gallons of supplemental water had to be added to maintain the water level near the 4-ft level. A seepage test is scheduled for 2014.

\subsection{Constituent Loading Rates}

As required by the current permit, loading rates are calculated for total dissolved solids (TDS), total nitrogen (TN), chemical oxygen demand (COD), and total phosphorus. The annual effluent constituent loading rates to the land application site for permit years 2004 through 2013 are presented in Table 4 . Loading rates were calculated based on application to the entire 73.5 acres. 
Table 4. Annual constituent loading rates. ${ }^{\text {a }}$

\begin{tabular}{ccccc}
\hline Year & $\begin{array}{c}\text { TDS } \\
\text { (lbs/acre) }\end{array}$ & $\begin{array}{c}\text { Total Nitrogen }^{\mathrm{b}} \\
(\text { lbs/acre) }\end{array}$ & $\begin{array}{c}\text { COD } \\
\text { (lbs/acre) }\end{array}$ & $\begin{array}{c}\text { Total } \\
\text { Phosphorus } \\
\text { (lbs/acre) }\end{array}$ \\
\hline 2004 & $\mathrm{NS}^{\mathrm{c}}$ & 0.83 & 35.21 & 0.24 \\
2005 & $1,078.67$ & 2.31 & 43.09 & 0.78 \\
2006 & 786.99 & 1.89 & 32.72 & 1.09 \\
2007 & 417.18 & 0.83 & 14.16 & 0.06 \\
2008 & 334.82 & 0.94 & 16.33 & 0.17 \\
2009 & 399.06 & 0.84 & 16.03 & 0.10 \\
2010 & 300.42 & 1.18 & 11.92 & 0.22 \\
2011 & 194.4 & $0.28^{\mathrm{d}}$ & 7.98 & 0.05 \\
$2012^{\mathrm{e}}$ & 0 & 0 & 0 & 0 \\
$2013^{\mathrm{e}}$ & 0 & 0 & 0 & 0
\end{tabular}

a. Loading rates calculated for wastewater application on 73.5 acres (hydraulic management unit MU-014101).

b. Total nitrogen is determined from the sum of the TKN and NNN results.

c. NS- Not sampled.

d. When nitrate + nitrite as nitrogen concentrations were reported as below the detection limit, half the detection limit was used to calculate the loading rate.

e. No wastewater was land applied.

Sampling and analysis of TDS in the wastewater became a requirement with the issuance of the 2005 permit (Johnston 2005). The previous permit did not require TDS sampling and analysis in either the influent or the effluent; therefore, 2005 was the first year that TDS was routinely analyzed in the effluent. Beginning with the 2005 total annual loading for TDS of 1,079 lbs/acre, the total annual loading rate has decreased each year to the 2012 and 2013 low of 0 lbs/acre. The decreasing loading rates are directly related to the decreasing volume of wastewater applied to the irrigation area.

The current permit does not specify a maximum total nitrogen loading rate. Beginning with the first application of wastewater in 1995, no source of nitrogen other than the CFA STP effluent wastewater, was applied to the application area. For the period of 2004 through 2013, the total nitrogen loading rate was the highest in 2005 at $2.31 \mathrm{lbs} /$ acre/year and lowest during permit years 2012 and 2013 at 0 lbs/acre/year (Figure 5). As a general rule, nitrogen loading should not exceed the amount necessary for crop utilization plus 50\%. However, wastewater is applied to desert steppe and crested wheat grass communities without nitrogen removal via crop harvest. To estimate nitrogen buildup in the soil under this condition, a nitrogen balance was prepared by CES, which estimated it would take 20 to 30 years to reach normal nitrogen agricultural levels in the soil (based on a loading rate of $32 \mathrm{lbs} /$ acre/year) (CES 1993). The extremely low nitrogen-loading rates have had a negligible effect on nitrogen accumulation in the soil. 


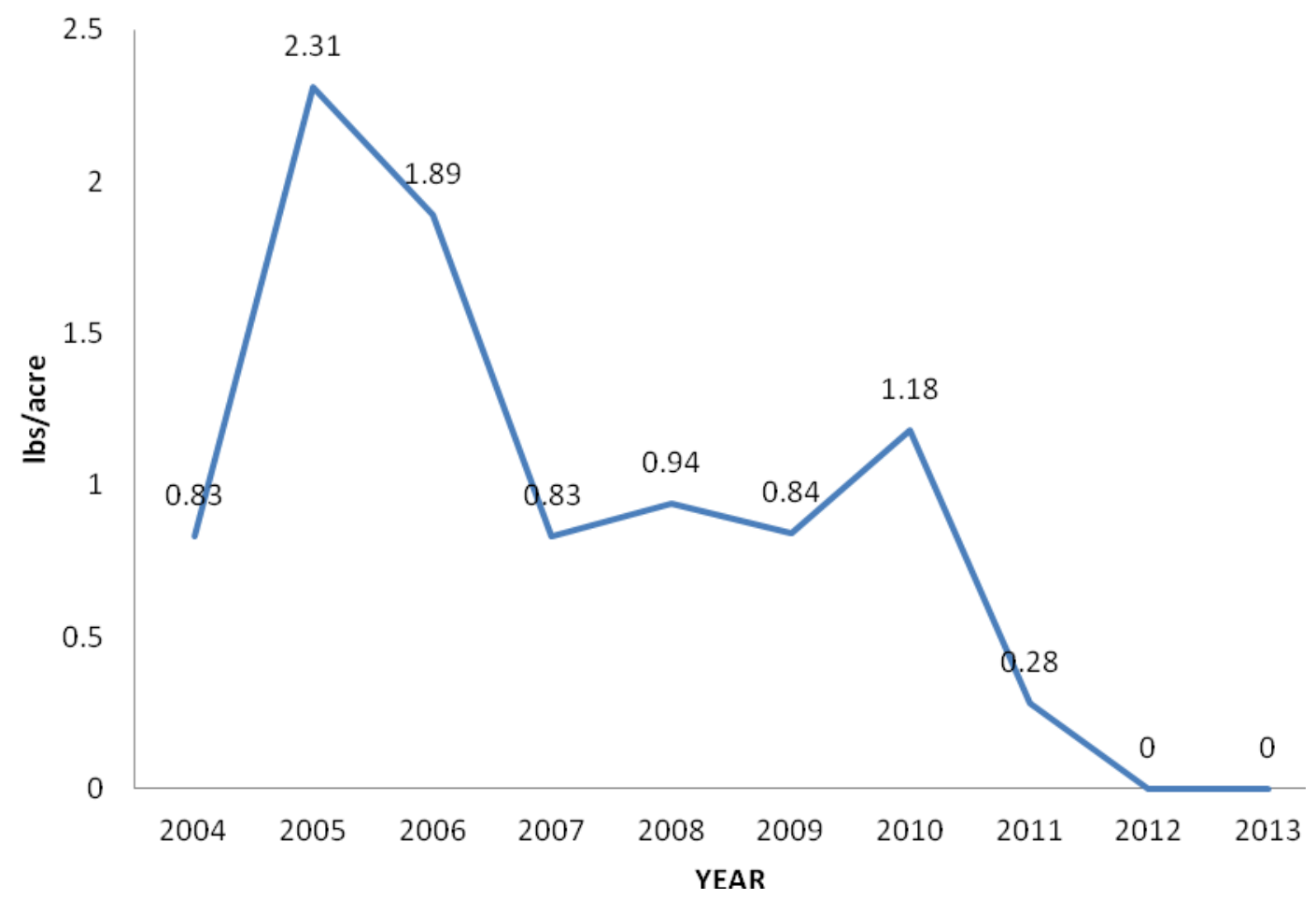

Figure 5. Total nitrogen annual loading rates for permit years 2004 through 2013.

The average growing season COD loading rates ranged from a low of 0 lbs/acre/year in 2012 and 2013 to a high of $43.09 \mathrm{lbs} /$ acre/year in 2005. The average growing season loading rate for the high in 2005 was only $0.20 \mathrm{lbs} /$ acre/day.

CES calculated a total phosphorous maximum loading rate of $4.5 \mathrm{lbs} / \mathrm{acre} / \mathrm{year}$ (CES 1993) for the land application site. Figure 6 shows the total phosphorus loading rates for permit years 2004 through 2013. The high occurred in 2006 at $1.09 \mathrm{lbs} /$ acre/year. The small amount of phosphorus applied was probably removed by sorption reactions in the soil and used by vegetation, rather than lost to ground water. 


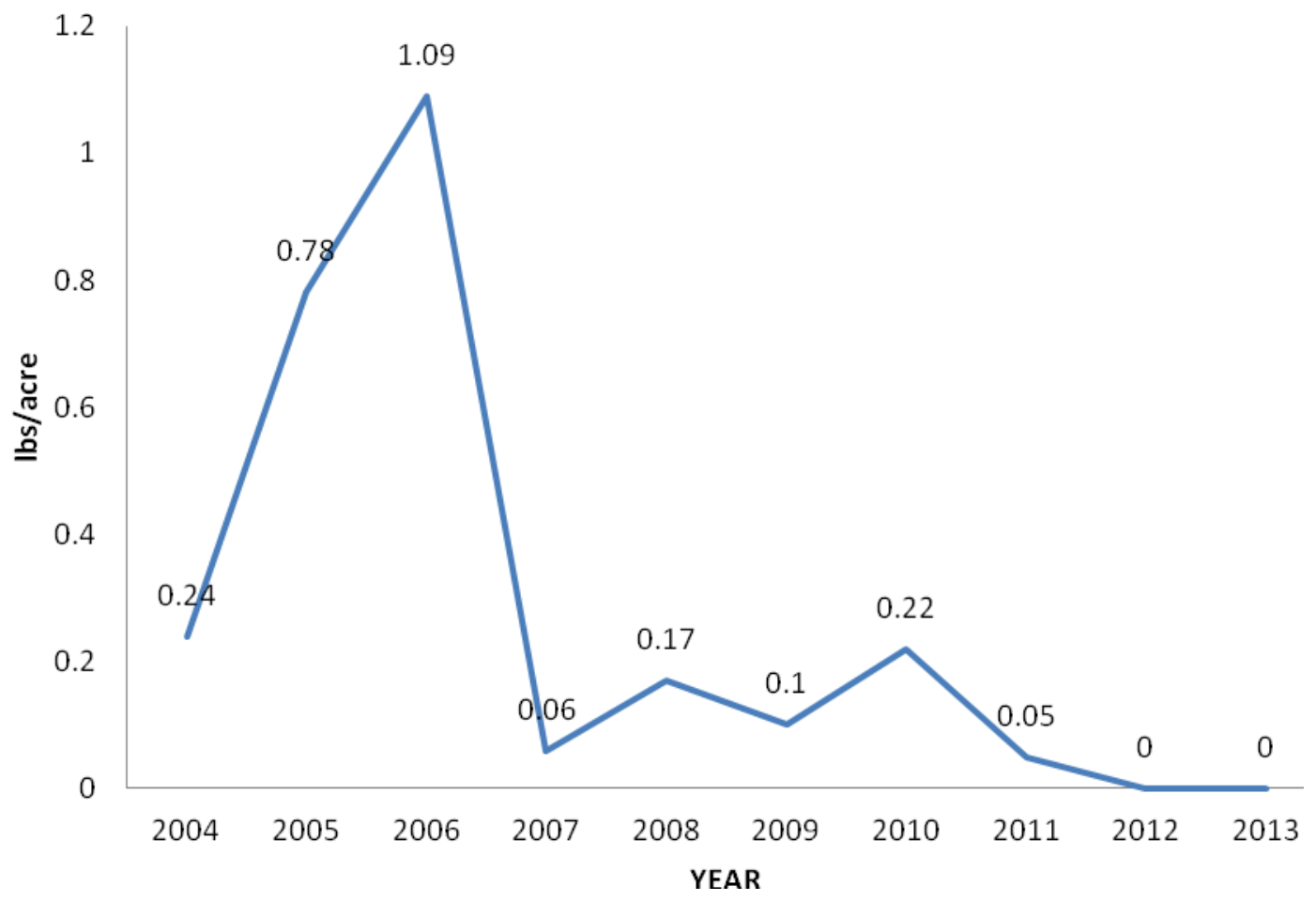

Figure 6. Total phosphorous annual loading rates for permit years 2004 through 2013. 


\section{SITE MANAGEMENT \\ 6.1 Compliance Activities}

\subsubsection{CA-141-01 - Plan of Operation}

A final Plan of Operation (O\&M Manual) for the wastewater reuse facility, incorporating the requirements of this permit shall be submitted to the Department for review and approval. The plan shall include a description of approved sample collection methods, appropriate analytical methods and companion QA/QC protocol. The manual may reference other written procedures required for the operation and maintenance of the wastewater reuse facility.

The permit was issued on March 17, 2010; therefore, the Plan of Operation is required to be submitted to the DEQ by March 17, 2011 for review and approval. The Plan of Operation was submitted to the DEQ on February 28, 2011 (Stenzel 2011b), and approved by DEQ on June 23, 2011 (Rackow 2011).

\subsubsection{CA-141-02 - Submittal of Seepage Rate Testing Procedure for the STP Lagoons}

The requirement was to submit a Seepage Testing Procedure to DEQ for review and approval for the three wastewater treatment lagoons by May 31, 2014. The procedure shall describe the testing procedures, equipment, measurement methods, and calculation methodology conclusions for DEQ review and approval.

The lagoon seepage test procedure was submitted to DEQ on May 12, 2014, (Mascareñas 2014) and approved on May 14, 2014 (Rackow 2014).

\subsubsection{CA-141-03 - Complete Seepage Testing of the Three CFA STP Lagoons}

The permit requires the seepage test to be completed by August 31, 2014. J-U-B Engineers have been subcontracted to perform the seepage tests.

On July 16, 2014, INL requested (Miller 2014) a 1-month extension of the seepage test completion date from August 31, 2014, until September 30, 2014, and to test the lagoons at a depth less than the 8-ft maximum design operation depth. The reason for the extension request was to allow for more time to fill Lagoons 2 and 3 prior to performing the test. The approved seepage test procedure requires the lagoons to be tested at the maximum design operation depth of 8-ft. Lagoons 2 and 3 were at approximately 4.5 -ft when the extension request was submitted. Lagoon 1 was at the 7 to 8 -ft level.

\subsection{Site Management Plans}

\subsubsection{Buffer Zone Plan}

The land application area is located on the INL Site where public access is restricted. Buffer zone distances required by the permit are shown in Table 5 . 
Table 5. Buffer zone distances from the Central Facilities Area land application area.

\begin{tabular}{|l|c|c|}
\hline & $\begin{array}{c}\text { Permit Required Buffer Zone } \\
\text { Distance (ft) }\end{array}$ & $\begin{array}{c}\text { Approximate Distance from } \\
\text { CFA Land Application Area } \\
(\mathrm{ft})\end{array}$ \\
\hline $\begin{array}{l}\text { Nearest Domestic Water } \\
\text { Well (Atomic City) }\end{array}$ & 500 & 42,000 \\
\hline Public Water Wells & 1,000 & 2,000 \\
\hline Surface Water & 100 & 16,000 \\
\hline $\begin{array}{l}\text { Public Access Areas } \\
\text { (Highway 20-26) }\end{array}$ & 1,000 & 4,400 \\
\hline
\end{tabular}

Fencing is not required by the current permit. However, posting is required every 500 feet and at each corner of the outer perimeter of the buffer zones at the site.

\subsubsection{Grazing Management Plan}

Domestic livestock grazing is not allowed on the application reuse area.

\subsubsection{Nuisance Odor Management Plan}

Wastewater generated at CFA is typically classified as "low strength" based on concentrations of COD, TN, and total phosphorus (Metcalf and Eddy 2003). Odors from the STP are generally not discernible at INL occupied areas or public access areas. Therefore, no odor management plan has been prepared nor is one considered necessary.

\subsubsection{Waste Solids Management Plan}

A waste solids management plan will be required prior to disposing of any waste solids.

\subsubsection{Runoff Management Plan}

The permit requires that runoff shall be managed in accordance with most recent runoff management plan approved by DEQ. The most recent runoff management plan is from 2006. The plan was submitted to DEQ for review and approval on January 26, 2006, (Mascareñas 2006a) and approved by DEQ (Rackow, letter not dated, internal correspondence date is August 14, 2006).

\subsection{Monitoring}

\subsubsection{Monitoring the Quantity of Land Applied Wastewater}

The current permit limits wastewater application to no more than 37 million gallons annually or 18.5 acre inches/acre per year to the 73.5 acre application area. The land application center pivot is equipped with a meter that records flow gallons. The flow meter is monitored daily when the pivot is operated. Flow readings are recorded by utility operators and results are included in annual performance reports. The pivot flow meter is removed and returned to the manufacturer for calibration periodically depending on elapsed time and volume pumped since the previous calibration (typically every 3 to 5 years). 


\subsubsection{Sampling and Analysis of Land-Applied Wastewater}

Due to the decreasing volume of wastewater, more recent operation of the pivot typically consisted of discharging wastewater for approximately 8 hours/day during a normal work week. Wastewater was typically discharged during a single month each year.

The permit allows for periods of discharge less than 24-hours. If the discharge is less than 24-hours, an appropriate number of flow-proportioned samples are collected to yield a representative sample. The number of samples necessary for adequate sampling is defined in the permit.

Monitoring Services (MS) at INL monitors effluent discharges at the CFA STP. This program involves sampling, analysis, and data interpretation carried out under a quality assurance program. MS performs monthly effluent monitoring as required in Section $\mathrm{G}$ of the permit for the CFA STP. Effluent samples are collected from the pump pit (sampling location WW-014102) prior to discharge to the pivot. All samples are collected according to established programmatic sampling procedures.

Effluent samples are taken during a preselected week each month following a randomly generated sampling schedule to represent normal operating conditions. All samples are analyzed using methods identified in 40 CFR 136, "Guidelines Establishing Test Procedures for the Analysis of Pollutants"; 40 CFR 141, "National Primary Drinking Water Regulations"; 40 CFR 143, "National Secondary Drinking Water Regulations"; or as approved by the DEQ. The $\mathrm{pH}$ and total coliform samples are collected as grab samples. The other permit required samples are collected as flow-proportional composite samples.

\subsubsection{Method of Calculating Hydraulic and Constituent Loading}

Treated wastewater is applied to relatively undisturbed desert soils and native vegetation. The wastewater is not used to irrigate agricultural crops or lands used for domestic animal grazing. Wastewater is only applied during the growing season (April 1 through October 31). As required by the permit, the growing season loading rate is not to exceed 18.5 inches/acre. During recent years, the amount of wastewater applied has continued to decline from 4.98 inches/acre in 2005 to the point that no wastewater was applied during the 2012 and 2013 permit years. The combined precipitation and applied wastewater is significantly less than the annual evapotranspiration rate. No loading credit is taken for removal by plants or by leaching.

Calculated monthly and annual loading rates are based on the following equations (INL 2011):

$$
\begin{aligned}
& \text { Hydraulic Loading }(\mathrm{gal} / \mathrm{acre})=\frac{\text { pivot gal. applied }}{73.5 \text { acres }} \\
& \text { Hydraulic Loading }(\mathrm{in} / \mathrm{acre})=\frac{\text { gal.applied }}{\text { acre }} \times \frac{1 \text { acre inch }}{27154 \mathrm{gal}} \\
& \text { Constituent Loading }(\mathrm{lb} / \mathrm{acre})=\frac{\text { gal. applied }}{\text { acre }} \times \frac{3.785 l}{\text { gal. }} \times \frac{\text { constituent } \mathrm{mg}}{l} \times \frac{1 \mathrm{lb}}{453590 \mathrm{mg}} .
\end{aligned}
$$

\subsubsection{Monitoring Supplemental Irrigation Water}

Application of supplemental (fresh) irrigation water is prohibited by the existing permit. No permit change is requested. If supplemental irrigation becomes necessary to leach salt from the soil, a separate request would be submitted to the DEQ. 


\subsubsection{Soil Monitoring}

The current permit required soil samples from the land application area to be collected in 2010 and 2013. All samples were collected in October of each year. Samples were collected from the 0-12, 12-24, and 24-36 inch depths. The results from the 2010 and 2013 sampling events and 2005 through 2009 are shown in Table 6.

Table 6. Central Facilities Area Sewage Treatment Plant application area soil monitoring results for the period of 2005 through 2013.

\begin{tabular}{|c|c|c|c|c|c|c|c|c|}
\hline Parameter & $\begin{array}{c}\text { Depth } \\
\text { (in.) }\end{array}$ & 2005 & 2006 & 2007 & 2008 & $2009^{a}$ & $2010^{b}$ & $2013^{c}$ \\
\hline \multirow[t]{3}{*}{$\mathrm{pH}$} & $0-12$ & 8.02 & 8.29 & 8.05 & 8.21 & 8.26 & 7.97 & 8.05 \\
\hline & $12-24$ & 7.94 & 8.05 & 8.00 & 7.88 & 7.95 & 7.85 & 8.07 \\
\hline & 24-36 & 8.03 & 8.15 & 8.09 & 8.00 & 8.05 & 7.85 & 8.05 \\
\hline \multirow{3}{*}{$\begin{array}{l}\text { Electrical Conductivity } \\
(\mathrm{mmhos} / \mathrm{cm})\end{array}$} & $0-12$ & 1.93 & 0.86 & 1.221 & 0.722 & 0.675 & 1.091 & 0.356 \\
\hline & $12-24$ & 2.86 & 3.20 & 2.03 & 2.66 & 2.490 & 2.660 & 1.281 \\
\hline & 24-36 & 2.10 & 3.54 & 1.95 & 2.20 & 1.937 & 2.590 & 1.516 \\
\hline \multirow{3}{*}{$\begin{array}{l}\text { Organic Matter } \\
(\%)\end{array}$} & $0-12$ & 1.49 & 1.76 & 1.33 & 1.49 & 1.51 & 1.72 & 1.43 \\
\hline & $12-24$ & 0.79 & 0.933 & 0.774 & 0.874 & 0.655 & 0.828 & 0.814 \\
\hline & $24-36$ & 0.46 & 0.562 & 0.483 & 0.867 & 0.424 & 0.603 & 0.521 \\
\hline \multirow{3}{*}{$\begin{array}{l}\text { Nitrate as Nitrogen } \\
(\mathrm{ppm})\end{array}$} & $0-12$ & 5.44 & 3.07 & 3.18 & 1.16 & 1.62 & 1.41 & 3.17 \\
\hline & $12-24$ & 1.66 & $1.003 \mathrm{U}^{\mathrm{d}}$ & $0.977 \mathrm{U}$ & $0.996 \mathrm{U}$ & $0.998 \mathrm{U}$ & $1.02 \mathrm{U}$ & $0.980 \mathrm{U}$ \\
\hline & $24-36$ & 1.73 & $0.998 \mathrm{U}$ & $1.00 \mathrm{U}$ & $0.986 \mathrm{U}$ & $0.996 \mathrm{U}$ & $1.01 \mathrm{U}$ & $0.958 \mathrm{U}$ \\
\hline \multirow{3}{*}{$\begin{array}{l}\text { Ammonium Nitrogen } \\
(\mathrm{ppm})\end{array}$} & $0-12$ & $0.49 \mathrm{U}$ & 1.99 & 0.516 & 1.46 & 0.818 & $0.512 \mathrm{U}$ & 1.08 \\
\hline & $12-24$ & $0.48 \mathrm{U}$ & $0.501 \mathrm{U}$ & $0.489 \mathrm{U}$ & $0.498 \mathrm{U}$ & $0.499 \mathrm{U}$ & $0.508 \mathrm{U}$ & $0.517 \mathrm{U}$ \\
\hline & 24-36 & $0.49 \mathrm{U}$ & $0.501 \mathrm{U}$ & $0.500 \mathrm{U}$ & $0.493 \mathrm{U}$ & $0.498 \mathrm{U}$ & $0.507 \mathrm{U}$ & $0.516 \mathrm{U}$ \\
\hline \multirow{3}{*}{$\begin{array}{l}\text { Extractable Phosphorus } \\
\text { (ppm) }\end{array}$} & $0-12$ & 13.10 & 10.60 & 9.05 & 11.2 & 7.77 & 15.4 & 8.88 \\
\hline & $12-24$ & 3.26 & 1.94 & 1.77 & 3.98 & 1.72 & 3.64 & 3.17 \\
\hline & 24-36 & 1.72 & $0.99 \mathrm{U}$ & 1.19 & 2.84 & 1.28 & 4.34 & 1.66 \\
\hline \multirow{3}{*}{$\begin{array}{l}\text { Sodium Adsorption } \\
\text { Ratio }\end{array}$} & $0-12$ & 5.64 & 9.68 & 3.79 & 4.06 & 3.83 & 4.32 & 2.44 \\
\hline & $12-24$ & 3.94 & 7.45 & 4.00 & 4.73 & 4.19 & 5.10 & 3.97 \\
\hline & $24-36$ & 3.12 & 10.00 & 3.69 & 3.48 & 2.5 & 4.62 & 3.07 \\
\hline \multicolumn{9}{|c|}{$\begin{array}{l}\text { a. During the } 2009 \text { sampling event, refusal was met at the } 23 \text { in. depth at Location } 1 \text {. The auger was moved allowing for the } \\
24-36 \text { in. depth sample to be collected. At sampling Location } 4 \text {, refusal was met at the } 30 \text {-in. depth. }\end{array}$} \\
\hline \multicolumn{9}{|c|}{$\begin{array}{l}\text { b. During the } 2010 \text { sampling event, refusal was met at } 18 \text { in. at Location } 4 \text {. The location was moved and additional sample } \\
\text { was collected from } 18-24 \text { in., completing the } 12-24 \text { in. depth sample. Refusal was again encountered at the } 30 \text { in. depth at } \\
\text { Location } 4 \text {, resulting in the sample being collected at a depth of } 24-30 \text { inches. }\end{array}$} \\
\hline \multicolumn{9}{|c|}{$\begin{array}{l}\text { c. During the } 2013 \text { sampling event, refusal was met at } 28 \text { in. at Location } 4 \text {. Therefore, the sample was collected at the } 24-28 \\
\text { in. depth at Location } 4 .\end{array}$} \\
\hline d. U flag indicates that th & esult was & ported as & low the lab & catory inst & nents mini & um detecti & limit. & \\
\hline
\end{tabular}


In general, the monitored soil parameters appear to remain fairly stable over time. However, there has been some fluctuation over the years.

A pH between 5.5 and 8.4 is suitable for most crops (DEQ 2007). For all soil depths, the pH ranged from a low of 7.84 to a high of 8.29 .

Organic matter serves many important functions in soil/plant treatment systems. In mineral soils it is usually less than $5 \%$. As expected, organic matter is the highest in the $0-12$ in. range $(1.43 \%)$ and lowest in the $24-36$ in. range $(0.521 \%)$.

Excessive salts can adversely affect soil and plant health. Conversely, low-to-moderate salinity, indirectly measured as electrical conductivity, may actually improve the physical conditions of some soils. Soil conductivity levels of $0-2$ millimhos per centimeter $(\mathrm{mmhos} / \mathrm{cm})$ are generally accepted to have negligible effects on plant growth. Soils with a conductivity of $2-4 \mathrm{mmhos} / \mathrm{cm}$ are considered to have moderately high soil salinity (DEQ 2007) and may restrict growth in very salt-sensitive crops. Conductivity ranged from a low of $0.356 \mathrm{mmhos} / \mathrm{cm}$ in the $0-12 \mathrm{in}$. depth level to a high of 3.54 $\mathrm{mmhos} / \mathrm{cm}$ at the 24-36 in. depth (Table 6).

The nitrogen data in Table 6 suggest negligible nitrogen accumulation from previous wastewater application. Nitrate as nitrogen $\left(\mathrm{NO}_{3}-\mathrm{N}\right)$ was detected in all samples at the $0-12$ in. depth with a high of $5.44 \mathrm{ppm}$ in 2005. With the exception of the 2005 samples, NO3-N at the 12-24 in. and 24-36 in. depths were below the laboratory instruments minimum detection level. Ammonium nitrogen $\left(\mathrm{NH}_{4}-\mathrm{N}\right)$ was detected above the laboratory instruments minimum detection level in the upper soil layer (0-12 in.) in several samples with a high of $1.99 \mathrm{ppm}$. All other samples collected for $\mathrm{NH}_{4}-\mathrm{N}$ were below the laboratory instruments detection level. The low soil-available nitrogen $\left(\mathrm{NH}_{4}-\mathrm{N}\right.$ and $\left.\mathrm{NO}_{3}-\mathrm{N}\right)$ concentrations suggest that the sagebrush and grass vegetation use most of the plant-available nitrogen and that the total nitrogen application in the past has been low.

DEQ guidance (DEQ 2007) recommends that to ensure there are no ground water contamination concerns, the phosphorus should be less than $30 \mathrm{ppm}$ (Olsen method used in these analyses) in the 24-36 in. soil depth. As shown in Table 6, the highest phosphorus concentration at the 24-36 in. depth was $4.34 \mathrm{ppm}$, and well below the level of concern.

NOTE: Soil sampling is currently a requirement in Section G, Table 5 of the permit. Because of the low volume of wastewater applied to the land application area and the low concentrations of the measured soil parameters, Idaho National Laboratory (INL) is requesting that the soil sampling requirement not be included the new permit.

\subsubsection{Groundwater Monitoring}

No groundwater monitoring is performed relevant to this land application site.

\subsubsection{Crop Uptake Values}

No crops are grown at this application site. Therefore, the determination of crop uptake values is unnecessary.

\subsubsection{Other Monitoring}

Previously, INL MS would collect an annual sample for metals and radionuclides during the years when wastewater was land applied. 


\subsubsection{Meteorological Monitoring}

Meteorological monitoring is not specifically performed for this land application site. However, as discussed in Section 4.2, NOAA operates a MOS at CFA. 


\section{SITE OPERATIONS AND MAINTENANCE \\ 7.1 Operator Information}

BEA operates, monitors, and maintains the land application site and associated wastewater treatment and collection systems for DOE-ID. CFA Utilities Operations personnel, working under the direct supervision of a licensed responsible charge operator, perform routine surveillances of the Sanitary Waste Collection System, Sewage Treatment Plant, and land application area 7 days a week.

\subsection{Operator Certification Credentials}

Responsible charge operators and other operating personnel for the CFA Sanitary Waste Collection System, Sewage Treatment Plant, Service Waste System, and land application are licensed through the State of Idaho Bureau of Occupational Licenses. Licenses of the personnel who currently operate and oversee the permitted wastewater systems at CFA are listed in Table 7.

Table 7. Central Facilities Area Sewage Treatment Plant wastewater system operators.

\begin{tabular}{|l|l|l|c|}
\hline \multicolumn{1}{|c|}{ Operator } & \multicolumn{1}{|c|}{ Wastewater System } & \multicolumn{1}{c|}{ License Number } & $\begin{array}{c}\text { License Expiration } \\
\text { Date }\end{array}$ \\
\hline Harwood, Kenton L & Wastewater Collection - Class I & WWC1-18665 & June 2, 2015 \\
\hline Harwood, Kenton L & Wastewater Treatment - Class II & WWT2-18941 & June 2, 2015 \\
\hline Harwood, Kenton L & $\begin{array}{l}\text { Wastewater Treatment - Land } \\
\text { Application }\end{array}$ & WWTLA-19482 & June 2, 2015 \\
\hline Jorgensen, Brian K & Wastewater Collection - Class I & WWC1-19473 & August 7, 2015 \\
\hline Lewis, Michael G & Wastewater Treatment - Class II & WWT2-18004 & September 6, 2015 \\
\hline Lewis, Michael G & $\begin{array}{l}\text { Wastewater Treatment - Land } \\
\text { Application }\end{array}$ & WWTLA-17424 & September 6, 2015 \\
\hline
\end{tabular}

\subsection{Other Party Operations and Maintenance}

Not applicable. BEA operates and maintains the CFA STP and land application processes. 


\section{REFERENCES}

Cascade Earth Sciences, "Soil Suitability Investigation for Land Application of Waste Water, Central Facilities Area, Idaho National Engineering Laboratory," CES-070893, July 8, 1993.

Clawson, K. L., G. E. Start, and N. R. Ricks, N. R., "Climatography of the Idaho National Engineering Laboratory, 2nd Edition," U. S. Department of Commerce, National Oceanic and Atmospheric Administration, DOE/ID-12118, December 1, 1989.

DEQ, "Guidance for Reclamation and Reuse of Municipal and Industrial Wastewater," Idaho Department of Environmental Quality, September 2007.

Graham, J. F., INL, to G. Eager, P.E., DEQ, and R. Huddleston, P.E., DEQ, “2006 Wastewater Land Application Site Performance Report for the Idaho National Laboratory Site's Central Facilities Area Sewage Treatment Plant," CCN 208627, February 27, 2007.

ICP, "2004 Wastewater Land Application Site Performance Reports for the Idaho National Engineering and Environmental Laboratory," ICP/EXT-04-00648, Idaho Completion Project, 2005.

INEL, "1995 Annual Wastewater Land Application Site Performance Reports for the Idaho National Engineering Laboratory,” INEL-96/0009, Idaho National Engineering Laboratory, 1996.

INL, "Operation and Maintenance Manual for the Central Facilities Area Sewage Treatment Plant," INL/EXT-10-20704, Idaho National Laboratory, February 2011.

Johnston, J., DEQ, to J. Etheridge, BBWI, and J. F. Kotek, DOE-ID, “Central Facilities Area Sewage Treatment Facility, Wastewater Land Application Permit No. LA-000141-02 (Municipal and Industrial Wastewater)," CCN 54793, January 26, 2005.

Mascareñas, C. S., INL to T. A. Rackow, DEQ, 2006a, “Transmittal of Waste Solids Mangement Plan, Runoff Management Plan, and Updated Plan of Operation for the Central Facilities Area Sewage Treatment Plant," CCN 20487, January 26, 2006.

Mascareñas, C. S., P.E., INL, to G. Eager, P.E., DEQ and R. Huddleston, P.E., DEQ, 2006b, “2005 Wastewater Land Application Site Performance Report for the Idaho National Laboratory's Central Facilities Area Sewage Treatment Plant," CCN 204402, February 16, 2006.

Mascareñas, C. S., INL, to G. Eager, P.E., DEQ, “2013 Annual Wastewater Reuse Report for the Idaho National Laboratory Site's Central Facilities Area Sewage Treatment Plant," CCN 232052, February $18,2014$.

Mascareñas, C. S., INL, to T. Rackow, P.E., DEQ, "Lagoon Seepage Testing Procedures for Central Facilities Area Sewage Lagoons Located at Idaho National Laboratory," CCN 233141, May 12, 2014.

Metcalf and Eddy, 2003, "Wastewater Engineering Treatment and Reuse, Fourth Edition," McGraw-Hill, page 186.

Miller, T. A., INL, to T. Rackow, P.E., DEQ, "Request for One-Month Seepage Testing Extension for Central Facilities Area Sewage Treatment Lagoons Located at Idaho National Laboratory," CCN 233573, July 16, 2014.

Neher, E., DEQ, to R. V. Furstenau, DOE-ID, and D. E. Coburn, BEA, "LA-000141-03 INL CFA Sewage Treatment Facility, Final Wastewater Reuse Permit," CCN 220416, March 17, 2010.

Ostenna, D. A., and D. R. H. O’Connell, “Big Lost River Flood Hazard Study,” Report 2005-2, U. S. Department of the Interior, Bureau of Reclamation, November 2005. 
Rackow, T. A., DEQ, to C. W. Mascareñas, INL, “Approval of the Runoff Management Plan for the Central Facilities Area Sewage Treatment Plant, Compliance Activity CA-141-06, Wastewater Land Application Permit LA-000141-02," CCN 206523, letter not dated, internal correspondence date is used, August 14, 2006.

Rackow, T., P.E., DEQ, to J. A. Stenzel, INL, "LA-000141-03 INL CFA STP, CA-141-03 Plan of Operation Approval," CCN 224596, June 23, 2011,.

Rich, J., NOAA, email to M. Lewis, INL, "INL Precipitation and CFA Thermoscreen Tables for June 2014," CCN 233539, July 9, 2014.

Stenzel, J., INL, to G. Eager, P.E., DEQ, and R. Huddleston, P.E., DEQ, "Idaho National Laboratory 2007 Wastewater Land Application Site Performance Report for Central Facilities Area Sewage Treatment Plant," CCN 212694, February 26, 2008.

Stenzel, J., INL, to G. Eager, P.E., DEQ, and R. Huddleston, P.E., DEQ, “2008 Wastewater Land Application Site Performance Report for the Idaho National Laboratory Site's Central Facilities Area Sewage Treatment Plant," CCN 216249, February 26, 2009.

Stenzel, J., INL, to G. Eager, P.E., DEQ, and R. Huddleston, P.E., DEQ, "2009 Wastewater Land Application Site Performance Report for the Idaho National Laboratory Site's Central Facilities Area Sewage Treatment Plant," CCN 219715, February 25, 2010.

Stenzel, J., INL, to G. Eager, P.E., DEQ, 2011a, "2010 Annual Wastewater Reuse Report for the Idaho National Laboratory Site's Central Facilities Area Sewage Treatment Plant," CCN 223007, February 24, 2011.

Stenzel, J. A., INL, to T. Rackow, P.E., DEQ, 2011b, "Submittal of the Operation and Maintenance Manual for the Central Facilities Area Sewage Treatment Plant," CCN 223445, February 28, 2011.

Stenzel, J., INL, to G. Eager, P.E., DEQ, “2011 Annual Wastewater Reuse Report for the Idaho National Laboratory Site's Central Facilities Area Sewage Treatment Plant,” CCN 226342, February 15, 2012.

Stenzel, J., INL, to G. Eager, P.E., DEQ, “2012 Annual Wastewater Reuse Report for the Idaho National Laboratory Site's Central Facilities Area Sewage Treatment Plant,” CCN 229491, February 21, 2013.

USDA/SCS, 1981 Soil Survey Manual, 430-V-SSM, 1981. 